\title{
The HIV's Transmission from the Mother to the Child at the Community Hospital Center of Bangui (Central African Republic)
}

\author{
N. R. Ngbale ${ }^{1 *}$, C. E. Gaunefet ${ }^{1}$, A. Koïrokpi ${ }^{1}$, G. D. Kossa-ko-Ouakoua1, \\ S. Matoulou-Mbala-Wa-Ngogbe1, S. Ouapou'1, A. Manirakiza'², L. Kobangue ${ }^{3}$, A. Sepou' ${ }^{1}$ \\ ${ }^{1}$ Gynaecology-Obstetrics Service of the Bangui Community Hospital, Bangui, Central African Republic \\ ${ }^{2}$ Department of Public Health of the University of Bangui, Bangui, Central African Republic \\ ${ }^{3}$ Dermatology-Venerology Service of the CNHU of Bangui, Bangui, Central African Republic \\ Email: ^ngbaler@yahoo.fr
}

How to cite this paper: Ngbale, N.R., Gaunefet, C.E., Koïrokpi, A., Kossa-ko-Ouakoua, G.D., Matoulou-Mbala-Wa-Ngogbe, S., Ouapou, S., Manirakiza, A., Kobangue, L. and Sepou, A. (2020) The HIV's Transmission from the Mother to the Child at the Community Hospital Center of Bangui (Central African Republic). Open Journal of Obstetrics and Gynecology, 10, 802-808. https://doi.org/10.4236/ojog.2020.1060074

Received: May 6, 2020

Accepted: June 9, 2020

Published: June 12, 2020

Copyright ( 2020 by author(s) and Scientific Research Publishing Inc. This work is licensed under the Creative Commons Attribution International License (CC BY 4.0).

http://creativecommons.org/licenses/by/4.0/ (c) (i) Open Access

\begin{abstract}
Objective: Assess the impact of B + option on mother-to-child HIV's transmission at the community university hospital center after 4 years of use. $\mathrm{Pa}$ tients and methods: This was a retrospective and analytical study from January 1st 2015 to December 31st 2018 i.e. 4 years. The population's study was on HIV-positive mothers and their infants care in the service. Results: A total of 323 files of infants born from HIV-positive mothers were selected and having performed the PCR. 9 of them were HIV positive representing a rate of $2.79 \%$ mother-to-child HIV's transmission. This prevalence was $1.1 \%$ for women who started ART before and during pregnancy. The average age of newborns was 29 years. Mothers were literally rating in $24.15 \%$ during the period of starting antiretroviral therapy, $63 \%$ during pregnancy and $19 \%$ before pregnancy. For the delivery's way 295 delivered vaginally; they represented 91.33\%. Cesarean delivery was $8.67 \%$. Exclusive breastfeeding represented $87.31 \%$ of the diet. Mothers who started ARV therapy during the labor and after delivery were more likely to transmit HIV to their infants than mothers who started ART before and during pregnancy $(p=0.01)$. The other risk factors were represented by premature rupture of the membranes $(p=0.0001)$, hours of labor ( $p=0.0001)$, use of suction cup ( $p=0.0005)$, birth weight less than $2500 \mathrm{~g}(\mathrm{p}=0.00)$. Conclusion: Mother-to-child HIV's transmission still remains a public health problem at the Community University Hospital.
\end{abstract}

\section{Keywords}

Transmission, HIV, Community Hospital 


\section{Introduction}

For several years, the fight against the human immunodeficiency virus (HIV) has been a public health issue. A woman infected with HIV can transmit the virus to her baby during pregnancy, labor, delivery or breastfeeding. In the absence of any intervention, the risk of mother to child transmission (MTCT) of HIV is $15 \%$ to $30 \%$. The World Health Organization (WHO) estimates that 3.3 million children living with HIV in 2012 were infected mainly vertically, and $90 \%$ of these infections had occurred in sub-Saharan Africa. In developed countries, the risk of MTCT for HIV has been reduced to less than 1\% [1]. For more than 10 years, the Central African Republic has been developing a program to prevent mother-to-child transmission of HIV that covers the whole country, based on Niverapine prophylaxis to pregnant women and infants. Despite these interventions, the number of children infected with HIV remains high at $8 \%$. That's why in 2015 the B + option was adopted, which consists of systematic administration for life of the anti-retroviral triple therapy to pregnant or lactating women regardless of the $\mathrm{CD} 4$ count. In order to achieve the objectives of eliminating mother-to-child transmission of HIV [2], our study therefore proposes to assess the impact of the $\mathrm{B}+$ option on the transmission after 4 years of use.

\section{Patients and Methods}

It was a retrospective and analytical study from January 1st 2015 to December 31st 2018, 4 years. The study's population was on HIV-positive mothers and their infants care in the service. The study included all HIV-positive women who started HAART with combination therapy (Efavirenz $600 \mathrm{mg}$, Emtricilabine 200 $\mathrm{mg}$ and Tenofovir $245 \mathrm{mg}$ ) before or during the pregnancy, as well as those who started ART during the labor. after their screening The newborns were followed up in the service: In the case of exclusive breastfeeding the newborn received Nevirapine $4 \mathrm{mg} / \mathrm{Kg}$ once a day up to a week after complete cessation of breastfeeding. In the case of replacement feeding newborns received Nevirapine 2 $\mathrm{mg} / \mathrm{Kg} /$ day as a single dose for 6 weeks or Zidovudine $2 \mathrm{mg} / \mathrm{Kg}$ twice a day for 6 weeks. A first Polymerase Chain Reaction (PCR) screening was carried out at six weeks of life. If the test result (PCR1) is positive, the infant was referred to Pediatrics to start antiretroviral therapy (ART). If the test is negative and the infant is on exclusive breastfeeding, a second test (PCR2) was performed six weeks after stopping breast milk. Data's input and analysis were carried out using Word 2013, Excel 2013 and Epi-info software version 7.1.3.3. The statistical test used for the compare was ch-2 with a significance level $p<0.05$. The Fisher test was used when the workforce used was less than 5 .

RESULTS: In total, out of 323 files of infants born from HIV-positive mothers selected and having carried out the PCR, 9 were HIV positive, representing a rate of $2.79 \%$ mother-to-child HIV's transmission This rate was $1.1 \%$ for women who started ART before and during pregnancy. The average age of newborns was 29 with extremes 15 to 45 . The mothers were literally rate in $24.15 \%$ and the 
primary level in $44.58 \%$. The majority of mothers were pauciparous during the period of starting antiretroviral therapy $63 \%$ during pregnancy and $19 \%$ before pregnancy. The 233 women who achieved CD 4 counts, $49.3 \%$ had a CD 4 count below 350. Hours of labor were normal in 86.07 parturients. Pregnant women who gave birth after a premature rupture of the membranes represented $4.33 \%$. For the delivery's way 295 delivered vaginally; they represented $91.33 \%$. Cesarean delivery was $8.67 \%$. Out of 323 registered infants, 117 (36.22\%) were boys and $206(63.78 \%)$ were girls. Exclusive breastfeeding represented $87.31 \%$ of the diet. Mothers who started ARV therapy during labor and after delivery were more likely to transmit HIV to their infants than mothers who started ART before and during pregnancy $(\mathrm{p}<0.01)$. The other risk factors were represented by premature rupture of the membranes $(\mathrm{p}<0.0001)$, hours of work $(\mathrm{p}<0.0001)$, use of suction cup ( $\mathrm{p}<0.0005)$, birth weight less $2500 \mathrm{~g}(\mathrm{p}<0.00)$, and episiotomy ( $\mathrm{p}<0.0009)$ (Figure 1 and Tables 1-4).

\section{ART start-up period}

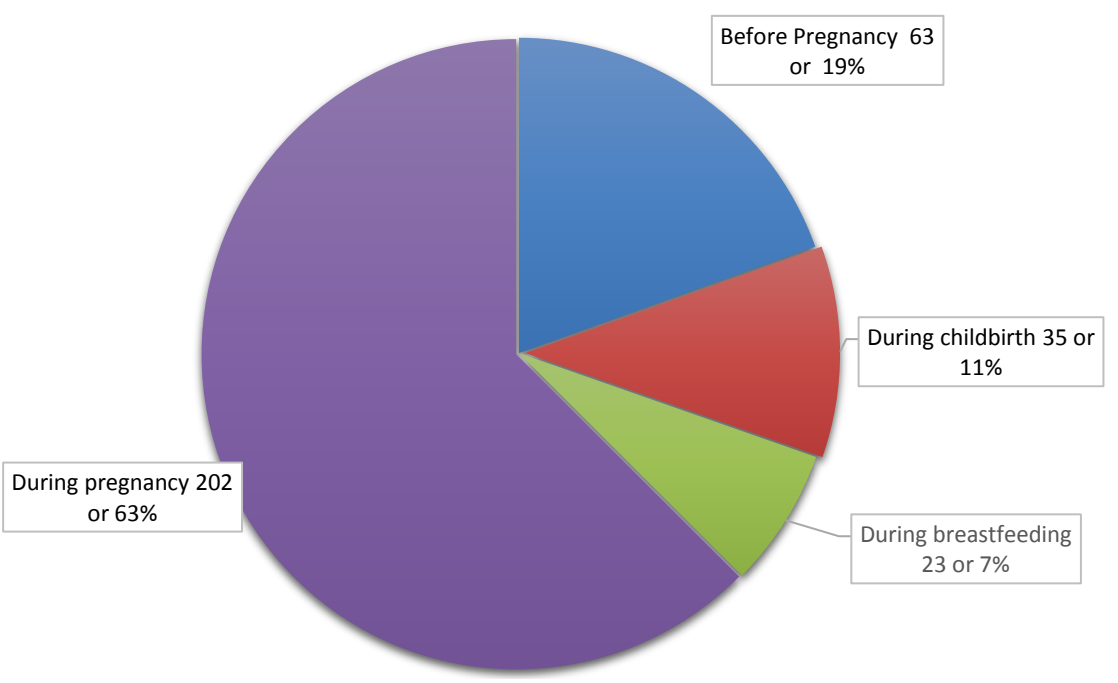

Figure 1. Distribution of mothers according to the period of start of treatment.

Table 1. Distribution of pregnant women according to the state of the membranes, working time, use of suction cup.

\begin{tabular}{ccc}
\hline & Number & Percentage \\
\hline Premature rupture of membranes & & \\
\hline No & 309 & 95.6 \\
Yes & 14 & 4.33 \\
Duration of labor & & \\
Undetermined & 15 & 4.64 \\
Extended & 30 & 9.29 \\
Normal & 278 & 86.07 \\
Total & 323 & 100.00 \\
\hline
\end{tabular}


Table 2. Distribution of infants according to whether the mother was delivered by episiotomy and use of suction cup.

\begin{tabular}{ccc}
\hline & Number & Pourcentage \\
\hline Episiotomy & & \\
No & 270 & 83.59 \\
Yes & 29 & 8.98 \\
Undetermined & 24 & 7.43 \\
Suction cup & & \\
No & 289 & 89.4 \\
Yes & 34 & 10.6 \\
Total & 323 & 100.00 \\
\hline
\end{tabular}

Table 3. Distribution of infants according to feeding method.

\begin{tabular}{ccc}
\hline Infant feeding & Number & Percentage \\
\hline Mixed breastfeeding & 12 & 3.71 \\
Exclusive breastfeeding & 282 & 87.31 \\
Artificial breastfeeding & 29 & 8.98 \\
Total & 323 & 100.00 \\
\hline
\end{tabular}

Table 4. Distribution of children according to HIV virological status and factors influencing HIV transmission.

\begin{tabular}{cccc}
\hline \multicolumn{4}{c}{ Treatment start period } \\
\hline & HIV positive & HIV negative & $\mathrm{p}$ \\
\hline During labor and after childbirth & 6 & 52 & 0.01 \\
Before and during pregnancy & 3 & 262 & \\
Premature rupture of membranes & & & 0.0001 \\
Yes & 6 & 8 & \\
No & 3 & 306 & \\
Duration of labor & & & \\
extended & 8 & 22 & \\
Normal & 1 & 277 & \\
Birth weight & & & \\
$<2500 \mathrm{~g}$ & 7 & 107 & 0.0001 \\
$\geq 2500 \mathrm{~g}$ & 2 & 214 & \\
\hline
\end{tabular}

\section{Discussion}

The diagnosis of HIV/AIDS in infants before the age of 3 months is made by polymerase chain reaction (PCR). PCR detects the virus itself in the blood (or blood cells). In our study, the transmission rate was $2.79 \%$ at PCR 1 over the entire population studied, this rate is close to those achieved in Mali and Ivory Cost which were respectively $1.98 \%$ and $3.28 \%$ [3] [4]; different from that one of 
Ngeumbi in 2004 which was $17.4 \%$ [5], of Ngbale in 2013 carried out in the same service had a rate of $8.3 \%$ [6]. This difference is justified by the protocol used at the time which was $\mathrm{A}+$ option that consisted in administering a monotherapy based on nevirapine alone whereas in our series $82 \%$ of women before and during pregnancy were already on antiretroviral triple therapy for their own health by reducing the viral load and the risk of mother-to-child transmission. The average age was 29 with extremes of 15 to 45 . This average age is practically the same as that one found by SANON in Senegal [7]. The average age varying from one country to another can be explained by the weight of culture and lifestyle on sexual behavior. In the Central African Republic, women enter sex early, as SEPOU noted during a study on sexual parameters among Central African women in urban areas [8]. Understanding and assimilating the messages given by health education services are easier for women with a certain level of education. Several studies have shown that uneducated women have more health problems than those with less education [9] [10].

Screening is the gateway to prevention and care [11] [12]. For example, mothers who were screened before or during pregnancy have had the privilege of receiving interventions to reduce the risk of mother-to-child HIV's transmission. Administering ARVs during pregnancy and childbirth effectively reduces mother-to-child transmission of the virus. These treatments reduce the risk of MTCT by decreasing the replication of the virus in the mother on the one hand, and on the other hand by ensuring prophylaxis in the infant during and after his exposure to the virus [7]. In our study, the mother-to-child transmission rate among women who were screened and put on treatment before and during pregnancy was $1.1 \%$, similar to studies done in France and Thailand which have proven their effectiveness with ARV treatment during pregnancy with a transmission rate that had gone from $15 \%$ to $1 \%$ after 10 years. A low CD4 count is an indicator of high viral load; more immunosuppression is advanced the higher the rate of transmission [7]. Ngwende's Zimbabwe study found that children born to mothers with low CD4 counts showed more risk to have HIV infection [13]. Other studies have found similar results reporting that women with a CD4 count $<200$ cells/ml were 5 times more likely to transmit HIV [14]. In our series, $49.30 \%$ of women had a CD4 $\leq 350 / \mathrm{mm}^{3}$. These women therefore had a high risk of transmitting HIV to their children; even if it's not statistically significant. Our result could be explained by the fact that most mothers with CD4 $\leq$ $350 / \mathrm{mm}^{3}$ during pregnancy were already receiving antiretroviral therapy. This could reduce the viral load and therefore the risk of mother-to-child HIV's transmission. Obstetric factors have been shown to influence the HIV's transmission between mother and child. In our cohort, obstetric factors such as prolonged labor, and premature rupture of the membranes were significantly associated. This observation is close to that one Landesman made during a prospective study by observing 522 deliveries he discovered that the duration of labor after rupture of the membranes represented a preponderant factor in the risk of perinatal HIV's transmission [15]. Generally, the use of a suction cup is accord- 
ing to the rule of art causes less trauma which reduces the risk of MTCT. In our series on 30 pregnant women who gave birth after applying a suction cup, four significantly transmitted HIV to their child. Our result corroborates that one of Tebeu in Cameroon [16]. Finally among the $82.04 \%$ of our patients who had started their treatment before and during pregnancy; $14 \%$ or $53.84 \%$ had been delivered by episiotomy. The MTCT of HIV among these was less than $1 \%$. It can be said that despite the use of episiotomy, the ARV treatment started early probably reduced the viral load thus reducing the risk of MTCT of HIV in a way significant. Children born with birth weight $<2500$ grams had a significantly increased risk of MTCT compared to those born with a weight $\geq 2500$ grams. This could be justified by the method of delivery of a low birth weight fetus which is made into a cannonball causing microtrauma for the AIDS virus to easily enter.

\section{Conflicts of Interest}

The authors declare no conflicts of interest regarding the publication of this paper.

\section{References}

[1] OMS (2012) Utilisation des Antirétroviraux pour traiter la femme enceinte et prévenir l'infection à VIH chez le nourrisson: Mise à jour pragmatique. 10. http://www.who.int/about/licensing/copyright form/en/index.html

[2] OMS. Organisation mondiale de la Santé. Département de lutte contre le VIH/sida. 20, Avenue Appia CH-1211 Genève 27 Transmission du VIH de la mère à l'enfant SUISSE Courriel: hiv-aids@who.int. http://www.who.int/hiv/fr

[3] Traore, Y., Dicko Traore, F. and Teguete, I. (2011) Prévention de la transmission mère enfant du VIH en milieu hospitalier africain, Bamako. Mali Medical, 1, 18-22.

[4] Lasme-Guillao, B.E., Sissoko, G.P. and Amon-Tanoh-Dick, F. (2011) Transmission mère enfant du VIH à Abidjan: Surmonter les obstacles socioculturels. Côte d'Ivoire. Médecine d' Afrique Noire, 58, 395-403.

[5] Ngembi, E., Yanza, M.C., Sepou, A., Ndoide, Y.M. and Gresenguet, G. (2004) Performance du projet de prévention de la transmission du VIH de la mère à l'enfant en République Centrafricaine. Bulletin Médical d Owendo, 24, 170-172.

[6] Ngbale, R.N., Komangoya, N.D., Diemer, H., Goddot-Nangouma, M.J.C., Gaunefet, C.E., Songo-Kette, K., Koïrokpi, A., Akilimali, P.Z. and Sepou, A. (2013) Difficultés de la prévention de la transmission du VIH de la mère à l'enfant dans les maternités au Sud du Sahara. Cas de l'Hôpital Communautaire de Bangui. Annals of African Medicine, 2, 1345-1351.

[7] Sanon, D.A. (2006) Evaluation du statut séro-immunologique des enfants nés de Mères séropositives au VIH suivies au centre de traitement Ambulatoire du service des maladies infectieuses Ibrahima Diop du CHU de Fann de Dakar. Thèse DEA en Population, Développement et Santé de la Reproduction, Dakar, 63 p.

[8] Sepou, A., Yanza, M.C., Domande-Modanga, Z. and Nguembi, E. (2002) Paramètres sexuels chez les femmes Centrafricaines en milieu urbain. Médecine d Afrique Noire, 49, 87-91.

[9] Sepou, A., Enza, J. and Nali, M.N. (2000) Les difficultés à l'expansion de la contraception en zones urbaine et semi-urbaine de la République Centrafricaine. Méde- 
cine d Afrique Noire, 47, 73-78.

[10] Desclaux, A., Sow, K., Mbaye, N. and Signate, S.Y.H. (2014) Passer de la prévention de la transmission mère-enfant du VIH à son élimination avant 2015: Un objectif irréaliste? Enjeux sociaux au Sénégal Médecine et Sante Tropical.

[11] Meda, N. (2010) Prévention de la transmission mère-enfant du VIH: État de lieux et nouvelles stratégies. Transcriptases, 143, 1-6.

[12] ONUSIDA (2003) Conseil et test VIH volontaires: Une voie d'accès à la prévention et aux soins. Genève, $104 \mathrm{p}$.

[13] Ngwende, S., Gombe, N.T., Midzi, S., Tshimanga, M., Shambira, G. and Chadambuk, A.A. (2013) Factors Associated with HIV Infection among Children Born to Mothers on the Prevention of Mother to Child Programme at Chitungwiza Hospital Zimbabwe 2008. BMC Public Health, 13, Article No. 1181. https://doi.org/10.1186/1471-2458-13-1181

[14] Iiff, P.J., Piwoz, E.G. and Tavengwa, N.V. (2005) Early Exclusive Breast Feeding Reduces the Risk of Post Natal HIV 1 Transmission and Increases HIV Free Survival. AIDS, 19, 699-708. https://doi.org/10.1097/01.aids.0000166093.16446.c9

[15] Landesman, S.H., Kalish, L.A. and Burns, D.N. (1996) Obstétrical Factor and the Transmission of Human Immunodeficiency Virus Type 1 from Mother to Child. The New England Journal of Medicine, 334, 1617-1623. https://doi.org/10.1056/NEJM199606203342501

[16] Tebeu, P.M., Kouam, L. and Obama Abena, M.T. (2004) Facteurs de transmission verticale du VIH: Augmentation potentielle chez l'adolescente; Cameroun. Médecine $d^{d}$ Afrique Noire, 51, 407-408. 